\title{
Lobate Lac Scale, Paratachardina lobata lobata (Chamberlin) (Hemiptera: Sternorrhyncha: Coccoidea: Kerriidae) ${ }^{1}$
}

F. W. Howard, Robert Pemberton, Avas Hamon, Greg S. Hodges, Bryan Steinberg, Catharine M. Mannion, David McLean, and Jeanette Wofford ${ }^{2}$

\section{Introduction}

A species of scale insect new to Florida is potentially one of the most devastating pests of trees and shrubs in the state's history. The lobate lac scale, Paratachardina lobata lobata (Chamberlin) (Hemiptera: Sternorrhyncha: Coccoidea: Kerriidae), a scale insect native to India and Sri Lanka, was found for the first time in Florida in August 1999 by personnel of the Florida Department of Agriculture and Consumer Services, Division of Plant Industry (DPI) (Hamon 2001). The identification of the species by Avas Hamon of DPI was confirmed by D. R. Miller of the Systematic Entomology Laboratory, U. S. Department of Agriculture, Beltsville, MD. This first record was on a hibiscus (Hibiscus rosa-sinensis) in the town of Davie (Broward County). The plant was destroyed by DPI personnel. Plants in the vicinity of this infested hibiscus were inspected without finding P. lobata lobata. However, the species was found again in 2000 on a Benjamin fig (Ficus benjamina) in Davie, on cocoplum (Chrysobalanus icaco) in Weston (Broward County), and on cocoplum at two sites in Miami (Miami-Dade County). In 2001, the scale insect species was found on 11 sites in Broward County and six sites in Miami-Dade County. In December 2001, DPI inspectors found P. lobata lobata in Lake Worth (Palm Beach County). As of October 2002, P. lobata lobata has been recorded from sites from Lake Worth on the north to Homestead (Miami-Dade County), a distance of $128 \mathrm{~km}$, and from the coast to $28 \mathrm{~km}$ inland. In 1992, specimens of scale insects submitted to DPI from the Bahamas had been identified as $P$. lobata lobata.

\section{Description and Biology}

The mature females of $P$. lobata lobata are about 1.5-2 $\mathrm{mm}$ long, and about the same width. The body has two pairs of prominent lobes. To the practiced eye, this scale insect's $\mathrm{x}$-shaped appearance is discernable, even without magnification. The testa is extremely hard and brittle, glossy and of a dark reddish brown color, but often appears dull and black

1. This document is EENY-276, one of a series of the Department of Entomology, Florida Cooperative Extension Service, Institute of Food and Agricultural Sciences, University of Florida. Date printed: November 2002. Revised: May 2004. Please visit the EDIS Website at http://edis.ifas.ufl.edu.

2. F. W. Howard, University of Florida; Robert Pemberton, USDA; Avas Hamon, Division of Plant Industry; Greg S. Hodges, Division of Plant Industry; Bryan Steinberg, University of Florida, Catharine M. Mannion, University of Florida; David McLean, Broward Community College and Nova Southeastern University; Jeanette Wofford, Cooper City Arborist. 
due to a coating of sooty-mold. The first instars (crawlers) are elongate-oval, deep red, and about 0.2 $\mathrm{mm}$ long. The characteristic lobate pattern develops in the second instar. The second instar female presumably molts to the adult female as in other scale insects. Males of this species have not been observed in Florida.

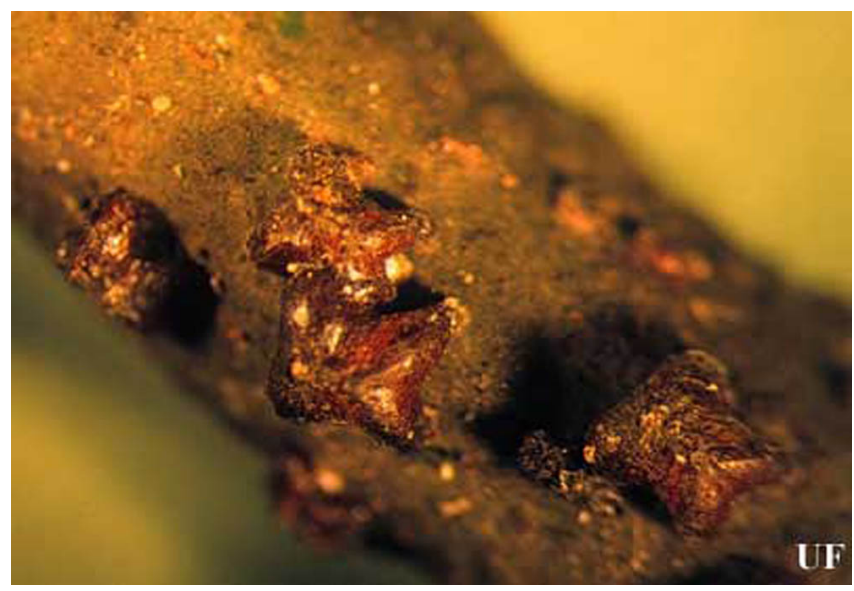

Figure 1. Mature females of lobate lac scale, Paratachardina lobata lobata (Chamberlin). Credits: F. W. Howard, University of Florida

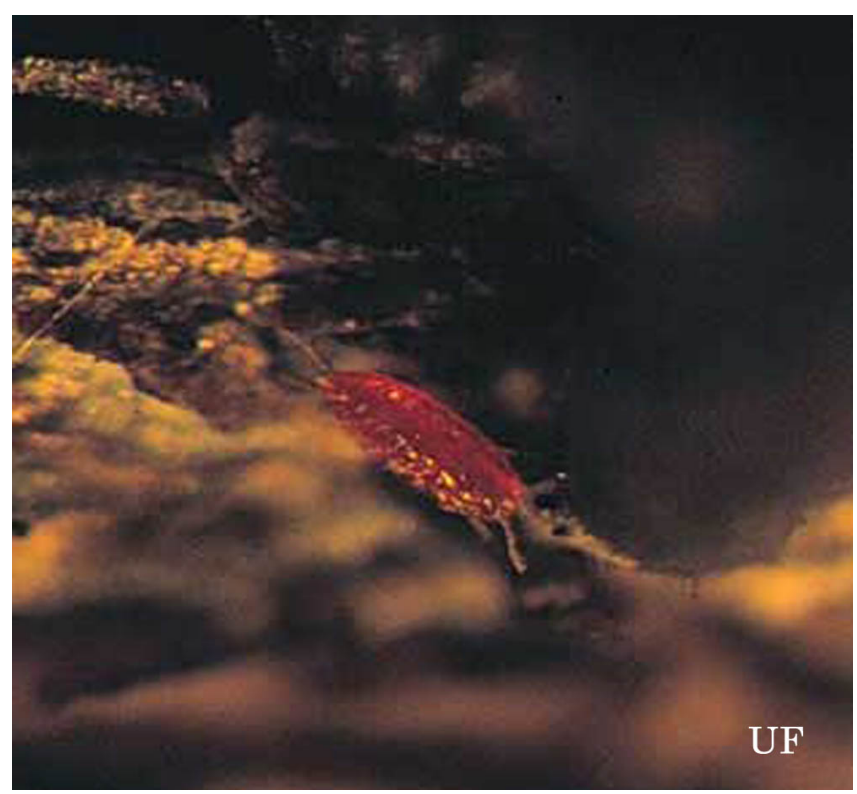

Figure 2. First instar (crawler) of lobate lac scale, Paratachardina lobata lobata (Chamberlin). Credits: F. W. Howard, University of Florida

Since the mature females of scale insects are wingless, they play no role in dispersal of populations to occupy new host plants. Scale insects rely mostly on passive dispersal of the crawler stage via air currents. Phoresis (being carried by birds and other animals) may be of some importance in some species.
Undoubtedly, movement of infested host plants from one locality to the next is a key factor in spreading scale insect pests in urban areas.

\section{The Lac Scale Family}

The species belongs to the lac scale family, Kerriidae, the best-known species of which is the true lac scale insect, Kerria lacca lacca (Kerr). The testa of the true scale insect has been utilized for centuries for making lacquer and similar products. However, most species of the family, including $P$. lobata lobata, do not produce any material of known commercial value. The specific scientific name, lobata, refers to the four prominent projections, or lobes, of this scale, and the vernacular name 'lobate lac scale' may be used for this species.

Of the 28 families of Coccoidea recognized by Miller and Ben-Dov (2002), 11 are represented by species native to Florida (Aclerdidae, Asterolecaniidae, Diaspididae, Cerococcidae, Coccidae, Conchaspidae, Eriococcidae, Kermesidae, Margarodidae, Ortheziidae, and Pseucococcidae). No species of Kerriidae is native to Florida and adjacent land areas. The Kerriidae is confined mostly to the tropics, with a minority of species found in low latitude desert areas. Of the 87 described species, 64 are distributed in the eastern hemisphere. Of the species native to the western hemisphere, 13 are reported from South America, six from Mexico (two of which are also reported in the southwestern U.S.), three reported only in the southwestern U.S., and one from Jamaica (Ben-Dove 2002).

\section{Effects on Host Plants}

Paratachardina lobata lobata has been found mostly on woody dicotyledonous plants. It infests the woody portions of twigs and small branches and less frequently main stems of usually $<2 \mathrm{~cm}$ in diameter, but usually not branches or main stems of $>2 \mathrm{~cm}$ in diameter. It has not been observed on foliage.

On highly susceptible hosts, the scale insects are crowded, forming a contiguous mass that appears as a dark, lumpy crust. On wax-myrtle (Myrica cerifera), a highly susceptible host, up to 42 mature females have been counted per $1 \mathrm{~cm}$ segment of twig. Sooty mold covers the branches, the insects themselves, and 


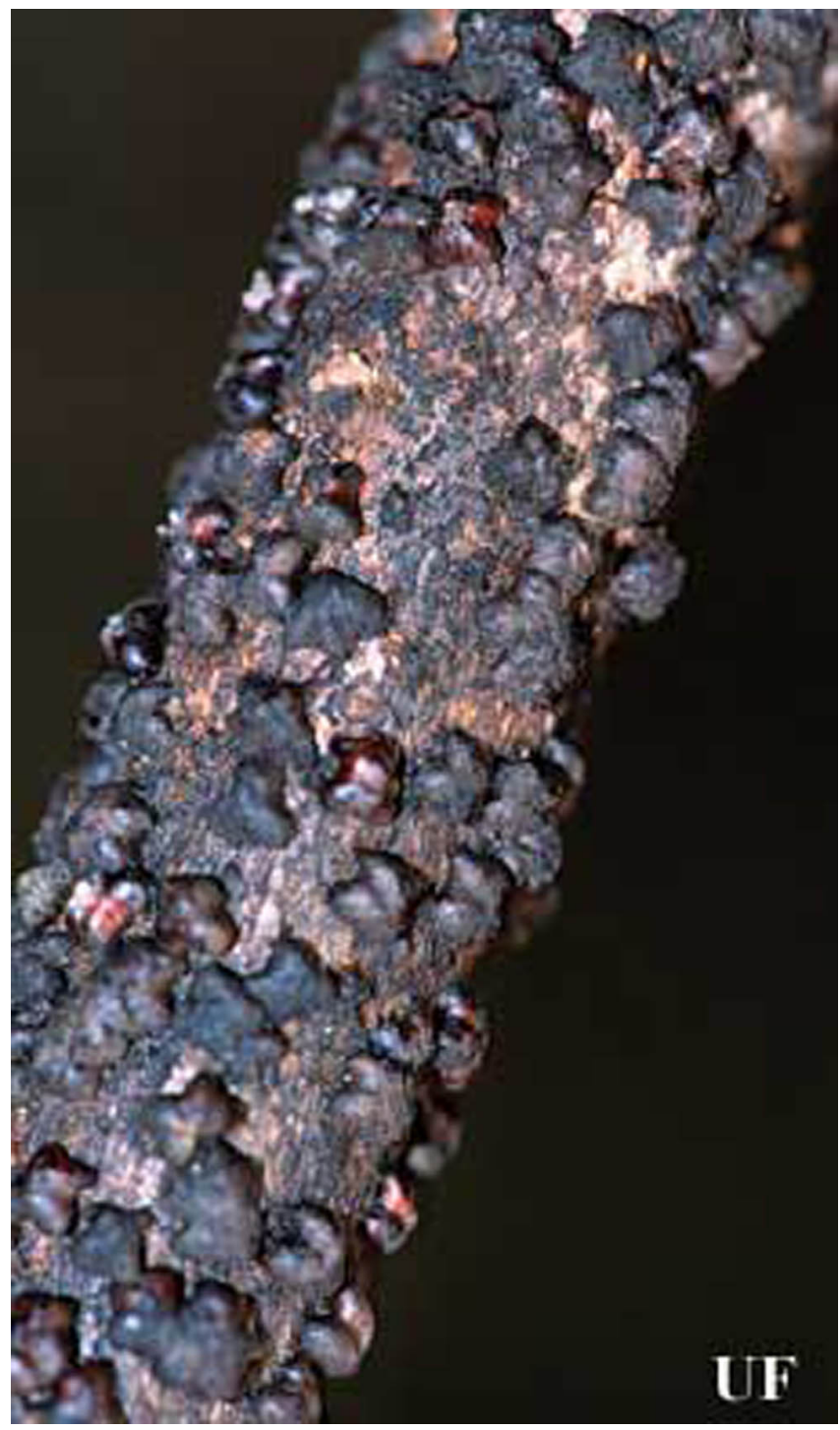

Figure 3. Wax-myrtle branch infested with lobate lac scale, Paratachardina lobata lobata (Chamberlin). Credits: F. W. Howard, University of Florida

occurs in patches on the foliage. Dense infestations are associated with branch dieback of some plant species, and in severe cases, highly infested shrubs and small trees have died. Wax-myrtle is especially prone to become heavily infested and die from the effects of lobate lac scale. Some plant species appear to tolerate dense infestations, but this may be illusory, as the long-term effects of such infestations are not yet known.

\section{Host Range}

This scale insect has been found on woody dicotyledonous plants, on one coniferous species, viz., southern red cedar, Juniperus silicicola, and on a palm, Phoenix roebelenii. As of October 2002, more

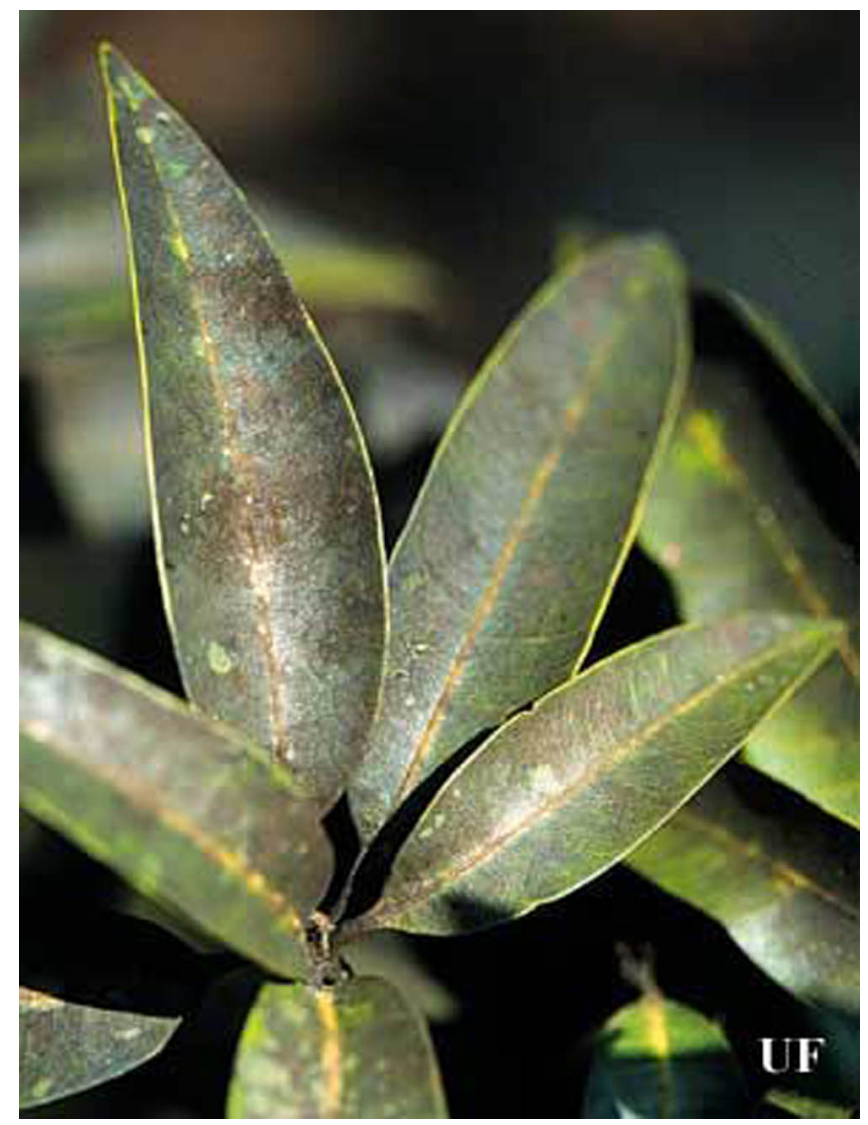

Figure 4. Sooty mold on mango leaves, an indirect result of infestation by lobate lac scale, Paratachardina lobata lobata (Chamberlin). Credits: F. W. Howard, University of Florida
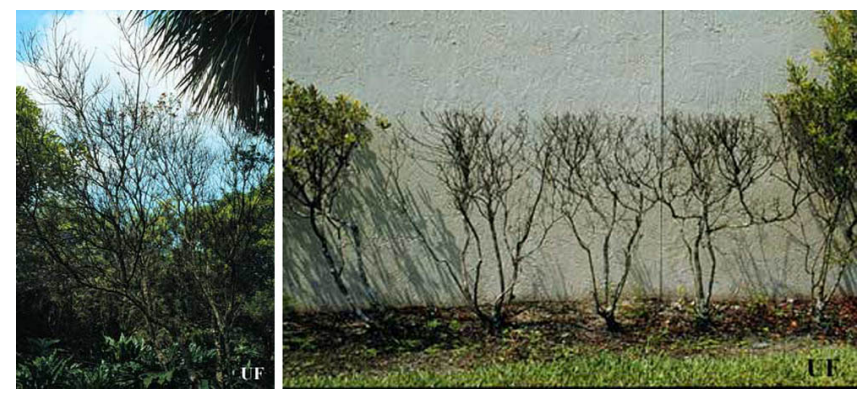

Figure 5. Wax-myrtles in the wild (left) and as a hedge (right) killed by infestations of lobate lac scale,

Paratachardina lobata lobata (Chamberlin). Credits: F. W. Howard, University of Florida

than 120 species in 44 families of woody plants have been determined to be hosts of $P$. lobata lobata in Florida (Tables $1 \& 2$ ). These include 39 plant species native to Florida. Most of the exotic host plants are grown as ornamental shrubs or trees, or as fruit trees. Some of these are extremely important in the urban landscape as shade trees, specimen trees, or hedges. Some plant families, notably Fabaceae, Myrtaceae, and Moraceae are especially well 
represented by species that serve as hosts, but this may be related to their abundance in the landscape or other biases. Plants at different sites have been exposed to infestations for different periods and infestation levels are highly variable. Differences in susceptibility have not been determined experimentally. However, certain species appear to be highly susceptible, including certain natives, e.g., wax-myrtle, cocoplum (Chrysobalanus icaco), buttonwood (Conocarpus erectus), strangler-fig (Ficus aurea), myrsine (Myrsine guianensis), red bay (Persea borbonia), and wild-coffee 1(Psychotria nervosa); popular exotic ornamental plants, e.g., black-olive (Bucida buceras), Indian laurel (Ficus microcarpa), Benjamin fig ( F. benjamina); and fruit trees, e.g., lychee (Litchi chinensis), mango (Mangifera indica), and star-fruit (Averrhoa carambola).

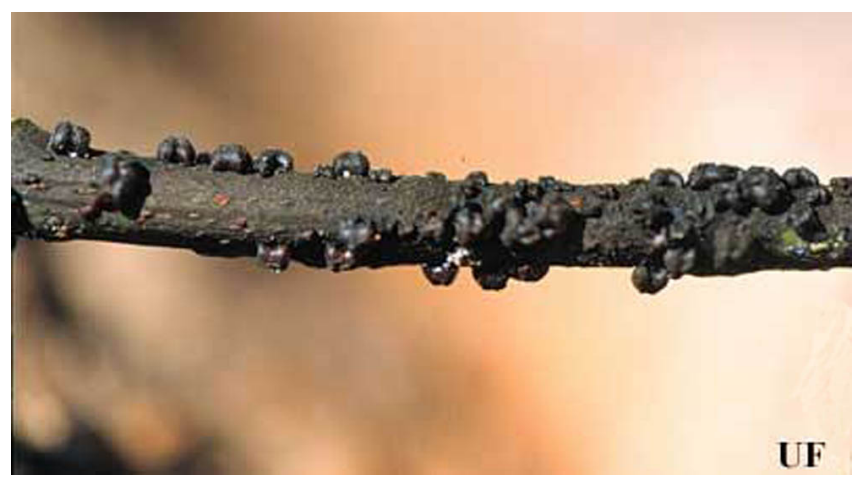

Figure 6. Twig of mango infested with lobate lac scale, Paratachardina lobata lobata (Chamberlin). Credits: F. W. Howard, University of Florida

\section{Potential Expansion in Distribution}

The potential for further spread of this scale insect in the western hemisphere is especially high for warm areas into which there is significant movement of living plants from Florida, e.g., Puerto Rico and other localities of the Caribbean Region, California, and Hawaii.

Invasion of natural areas is of paramount concern. A cursory examination in several tropical hardwood hammocks in Broward County revealed that there were heavy infestations on diverse species over large areas. The presence of heavy infestations $28 \mathrm{~km}$ inland, i.e., virtually at the eastern edge of the Everglades, implies that vegetation in this vast natural area is threatened. Most of the native host plants of $P$. lobata lobata identified in Florida are also distributed in the Caribbean Region, and if the insect were to be introduced into Puerto Rico or other Caribbean countries, natural areas there would likewise be threatened.

\section{Pest Management Prospects}

Virtually nothing has been published on the biology or control of this species. It has rapidly become a major pest in southeastern Florida, and it is urgent to initiate research on it. We have seen no evidence that this scale insect species has natural enemies in Florida.

Unpublished results of an experiment conducted at the University of Florida Fort Lauderdale Research $\&$ Education Center were that a root drench with the systemic insecticide imidacloprid effectively controlled $P$. lobata infesting large Benjamin fig trees. Further studies are being conducted to refine this method, and to test horticultural oils and additional chemical control methods. Because it is predicted that a very large percentage of trees and shrubs in both the urban and natural areas of Florida will become infested with this scale insect, we are investigating biological control as the only viable option for control in the long term.

\section{Selected References}

Hamon, A. (14 June 2001). Lobate lac scale, Paratachardina lobata lobata (Chamberlin) (Hemiptera: Kerriidae). Pest Alert. http://www.doacs.state.fl.us/ pi/enpp/ento/ paratachardina.html (30 October 2002).

Miller, D.R. and Y. Ben-Dov. (16 August 2002) ScaleNet http://www.sel.barc.usda.gov/scalenet/scalenet.htm (30 October 2002). 
Table 1. Lobate lac scale: Host list as of October, 2002

Compiled by F. W. Howard, David McLean, Robert Pemberton, Avas Hamon, Greg Hodges, Susan Halbert, and Jeanette Wofford. Additional contributors: Michael Brommet, John Cannon, Chris and Karolynne Griffiths, Way Hoyt, Andrew Southerland, Nancy Miller, and Laura Tooley.

* indicates species native to Florida.

Acacia auriculiformis Bentham (Fabaceae) - earleaf acacia

Acalypha wilkesiana Mueller (Eurphorbiaceae) - copperleaf

*Acer rubrum L. (Aceraceae) - red maple

Annona cherimola Miller X A. squamosa L. (Annonaceae) - atemoya

${ }^{*}$ Annona glabra L. (Annonaceae) - pond-appl

Annona muricata L. (Annonaceae) - soursop

Annona reticulata L. (Annonaceae) - custard-apple

Annona squamosa L. (Annonaceae) - sugar-appl

Antidesma bunius (L.) Stengel (Euphorbiaceae) - Bignay

*Ardisia escallanoides Schlechtendal \& Camisso (Myrsinaceae) - marlberry

Averrhoa carambola L. (Oxalidaceae) - carambola, starfrui

*Baccharis halimifolia L. (Asteraceae) - saltbush, groundsel-tree

Bauhinia sp. (Fabaceae)

Blighia sapida Konig (Sapindaceae) - akee

Brosimum alicastrum Swartz (Moraceae) - Mayan breadnut, ramón, cacique

Brunfelsia sp. (Solanaceae)

Brunfelsia nitida Bentham (Solanaceae) - lady-of-the-night

Brya ebenus (L.) DeCandolle (Fabaceae) - Jamaican raintree, West Indies ebony

Bucida buceras L.(Combretaceae) - black-olive, oxhorn bucida, ucar

${ }^{\star}$ Bumelia celastrina Humboldt, Bonpland \& Kunth (Sapotaceae) - saffron-plum

*Bursera simaruba (L.) Sargent (Burseraceae) - gumbo-limbo, almácigo

Calliandra haematocephala Hasskarl (Fabaceae) - powderpuff

Calliandra surinamensis (Fabaceae) - pink powderpuff

Callistemon viminalis Gaertner (Myrtaceae) - weeping bottlebrush

Calophylum brasiliense Cambess, des (Clusiaceae) - Brazilian beauty-leaf

${ }^{*}$ Calyptranthes pallens Grisebach (Myrtaceae) - spicewood

*Calyptranthes zuzygium (L.) Swartz (Myrtaceae) - myrtle-of-the-river

Cananga odorata (Lam ) J. D. Hooker \& T. Thomson (Annonaceae) - ylang-ylang

*Capparis cynophallophora L. (Capparaceae) - Jamaica caper tree

Casuarina equisetifolia L. (Casuarinaceae) - Australian-pine

*Celtis laevigata Willdenow (Celtidaceae) - sugarberry

Cestrum nocturnum L. (Solanaceae) - night-blooming jessamine

${ }^{*}$ Chrysobalanus icaco L. (Chrysobalanaceae) - cocoplum

Chrysophyllum cainito L. (Sapotaceae) - star-apple

*Chrysophyllum oliviforme L. (Sapotaceae) - satinleaf

Cinnamomum zeylanicum Blume (Lauraceae) - cinnamon

Citrus $X$ paradisi Macfadyen (Rutaceae) - grapefruit

Clausena lasium (Loureiro) Skeels (Rutaceae) - wampi

*Clusia rosea Jacquin (Clusiaceae) - pitch-apple, cupey

*Conocarpus erectus L. (Combretaceae) - buttonwood, mangle botón

Cupaniopsis anacardioides (A. Richard)Radlkofer (Sapindaceae) - carrotwood, tuckeroo

Diospyros digyna Jacquin (Ebenaceae) - black-sapote

*Dipholis salicifolia (L.) Alphonse DeCandolle (Sapotaceae) - willow bustic

Dovyalis hebecarepa (G. Gardner ) Warburg (Flacourtiaceae) - Ceylon gooseberry, kitembila

Elaeocarpus sp. (Elaeocarpaceae)

${ }^{*}$ Eugenia axillaris (Swartz) Willdenow (Myrtaceae) - white-stopper eugenia

Eugenia brasiliensis Lamarck (Myrtaceae) - grumichama 
Table 1. Lobate lac scale: Host list as of October, 2002

\section{Eugenia uniflora L. (Myrtaceae) - Surinam-cherry}

*Eugenia confusa DeCandolle (Myrtaceae) - redberry stopper

${ }^{*}$ Exothea paniculata (Jussieu) Radlkofer (Sapindaceae) - inkwood

${ }^{*}$ Ficus aurea Nuttall (Moraceae) - strangler fig

Ficus benjamina L. (Moraceae) - banyan fig

Ficus microcarpa (L.) (Moraceae) - Indian laurel

Ficus nota (Blanco) Merrill (Moraceae) - tibig

Ficus rubiginosa Ventenat (Moraceae) rusty leaf fig

Ficus salicifolia (Vahl) Berg (Moraceae) - willow-leaf fig

Filicium decipiens (Wight \& Arnot) Thwaites (Sapindaceae) - Japanese fern-tree

Fortunella japonica (Thunberg) Swingle (Rutaceae) - round kumquat

Garcinia prainiana King (Clusiaceae) - button mangosteen, serapu

Gardenia jasminioides Ellis (Rubiaceae) - gardenia

Grewia occidentalis L. (Tiliaceae) - starflower

Hamelia cuprea Grisebach (Rubiaceae) - Bahamas flame bush

*Hamelia patens Jacquin (Rubiaceae) - firebush

Hibiscus rosa-sinensis L. (Malvaceae) - hibiscus

*Ilex vomitoria Aiton (Aquifoliaceae) - yaupon holly

Inga affinis DeCandolle (Fabaceae) - ingá doce

*Juniperus silicicola (Small) Bailey (Cupressacae) - southern red-cedar

* Krugiodendron ferrum (Vahl)Urban (Rhamnaceae) - black ironwood

Lagerstroemia indica L. (Lythraceae) - crape-myrtle

Lagerstroemia speciosa (L.) Persoon (Lythraceae) - queen's crape-myrtle

Lansium domesticum Correa (Meliaceae) - duku, langsat

Laurus nobilis L. (Lauraceae) - laurel, sweetbay

Leonotis leonurus Brown (Lamiaceae) - lion's-ear

* Licaria triandra (Swartz) Kostermans (Lauraceae) - pepperleaf sweetwood

Litchi chinensis Sonnerat (Sapindaceae) - lychee

* Lysiloma latisiliqua (L.) Bentham (Fabaceae) - wild-tamarind

Lysiloma sabicu Bentham

Macadamia integrifolia Maiden \& Betch (Proteaceae) - macadamia nut

Macadamia tetraphylla L. A. S. Johnson (Proteaceae) - macadamia nut

Mangifera indica L. (Anacardiaceae) - mango

*Manilkara jaimiqui (C. Wright) Dubard ssp. Emarginata (L.) Cronquist (Sapotaceae) - wild-dilly

Manilkara (Achras) zapota (L.) Van Royen (Sapotaceae) - sapodilla, níspero

*Mastichodendron foetidissimum (Jacquin) H. J. Lam (Sapotaceae) - false-mastic

Melaleuca quiquenervia (Cavanilles) S.T. Blake (Myrtaceae) - cajeput

Melaleuca decora (Salisbury) Britten (Myrtaceae) white feather, honeymyrtle, paperbark, sweet tea-tree.

Melicocca bijuga L. (Sapindaceae) - Spanish-lime, mamoncillo

Michelia champaca L. (Magnoliaceae) - champaka

Mimusops elengi L. (Sapotaceae) - Spanish-cherry

Mussaenda erythrophylla Schumacher \& Thonning (Rubiaceae)

Myrciaria cauliflora (C. Martius) (Myrtaceae) - jaboticaba

*Myrica cerifera L. (Myricaceae) - wax-myrtle, southern bayberry

*Myrsine guianensis (Aublet) Kuntze (Myrsinaceae) - myrsine, rapanea

*Nectandra coriaceae (Swartz) Grisbach (Lauraceae) - lancewood

Ocimum sp. (Lamiaceae) - Thai basil

Pachystachys lutea Nees (Acanthaceae) - golden shrimp plant

*Parthenocissus quinqefolia (L.) Planchon (Vitaceae) - Virginia-creeper

Peltophorum pterocarpum (DeCandolle) K. Heyne (Fabaceae) - copperpod

Persea americana Miller (Lauraceae) - avocado

${ }^{*}$ Persea borbonia (L.) Sprengel (Lauraceae) - red bay 
Table 1. Lobate lac scale: Host list as of October, 2002

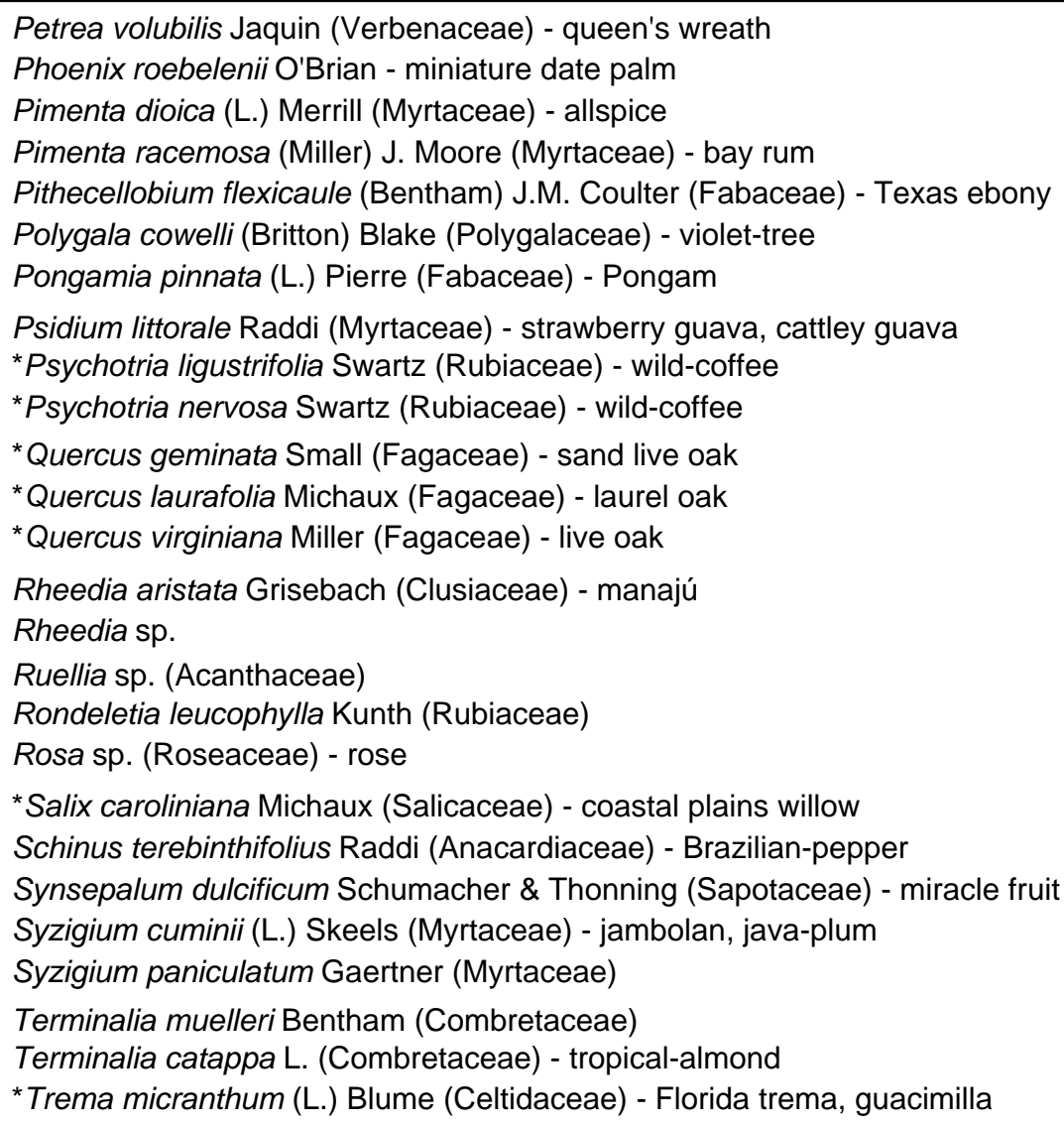

Table 2. Lobate lac scale: Host list by family as of October, 2002.

Compiled by F. W. Howard, David McLean, Robert Pemberton, Avas Hamon, Greg Hodges, Susan Halbert, and Jeanette Wofford. Additional contributors: Michael Brommet, John Cannon, Chris and Karolynne Griffiths, Way Hoyt, Andrew Southerland, Nancy Miller, and Laura Tooley.

${ }^{*}$ indicates species native to Florida.

\section{Acanthaceae}

Pachystachys lutea Nees - golden shrimp plant

Ruellia sp.

\section{Aceraceae}

${ }^{*}$ Acer rubrum L. - red maple

Aquifoliaceae

* Ilex vomitoria Aiton - yaupon holly

\section{Anacardiaceae}

Mangifera indica L.- mango

Schinus terebinthifolius Raddi - Brazilian-pepper 
Table 2. Lobate lac scale: Host list by family as of October, 2002.

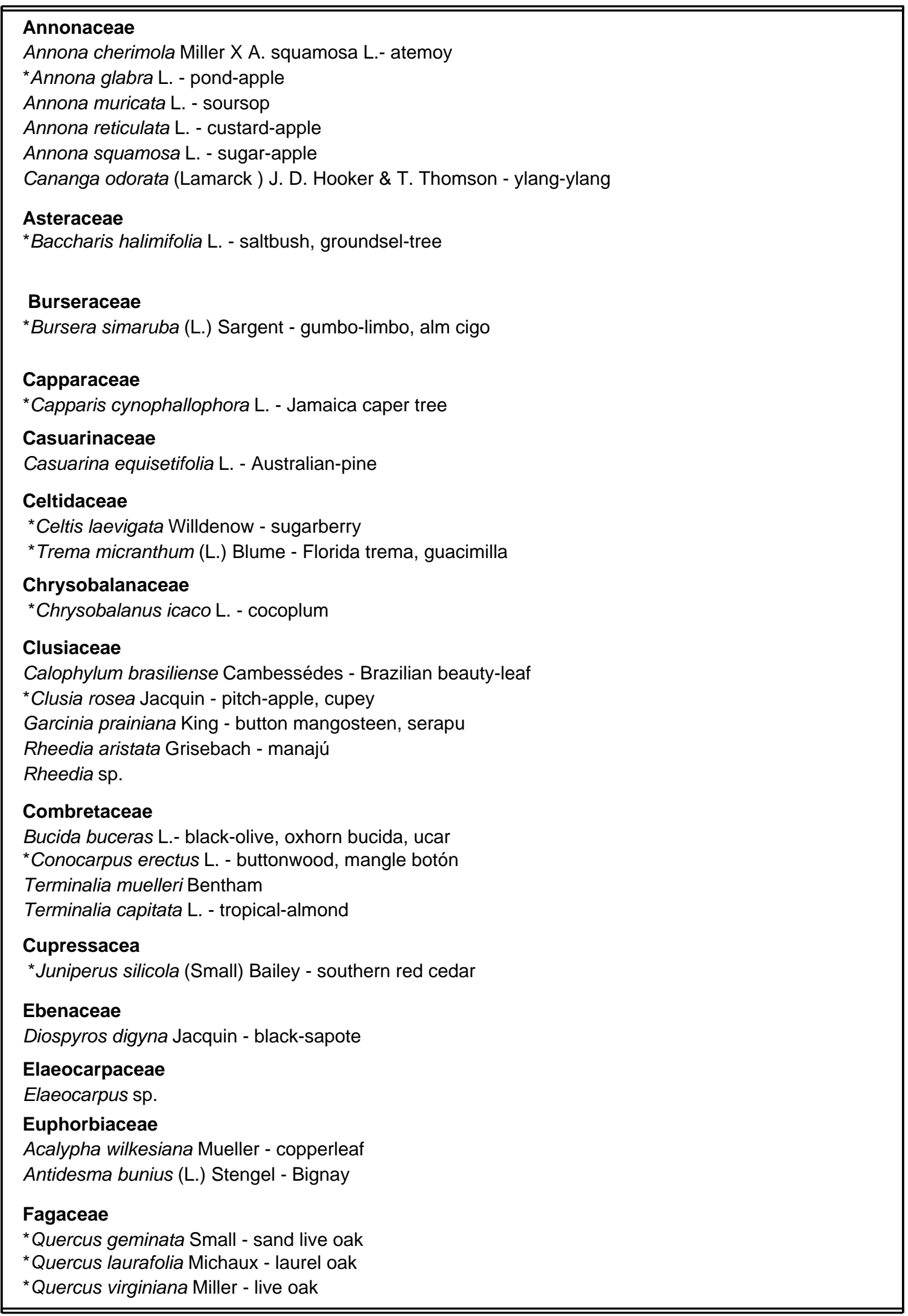


Table 2. Lobate lac scale: Host list by family as of October, 2002.

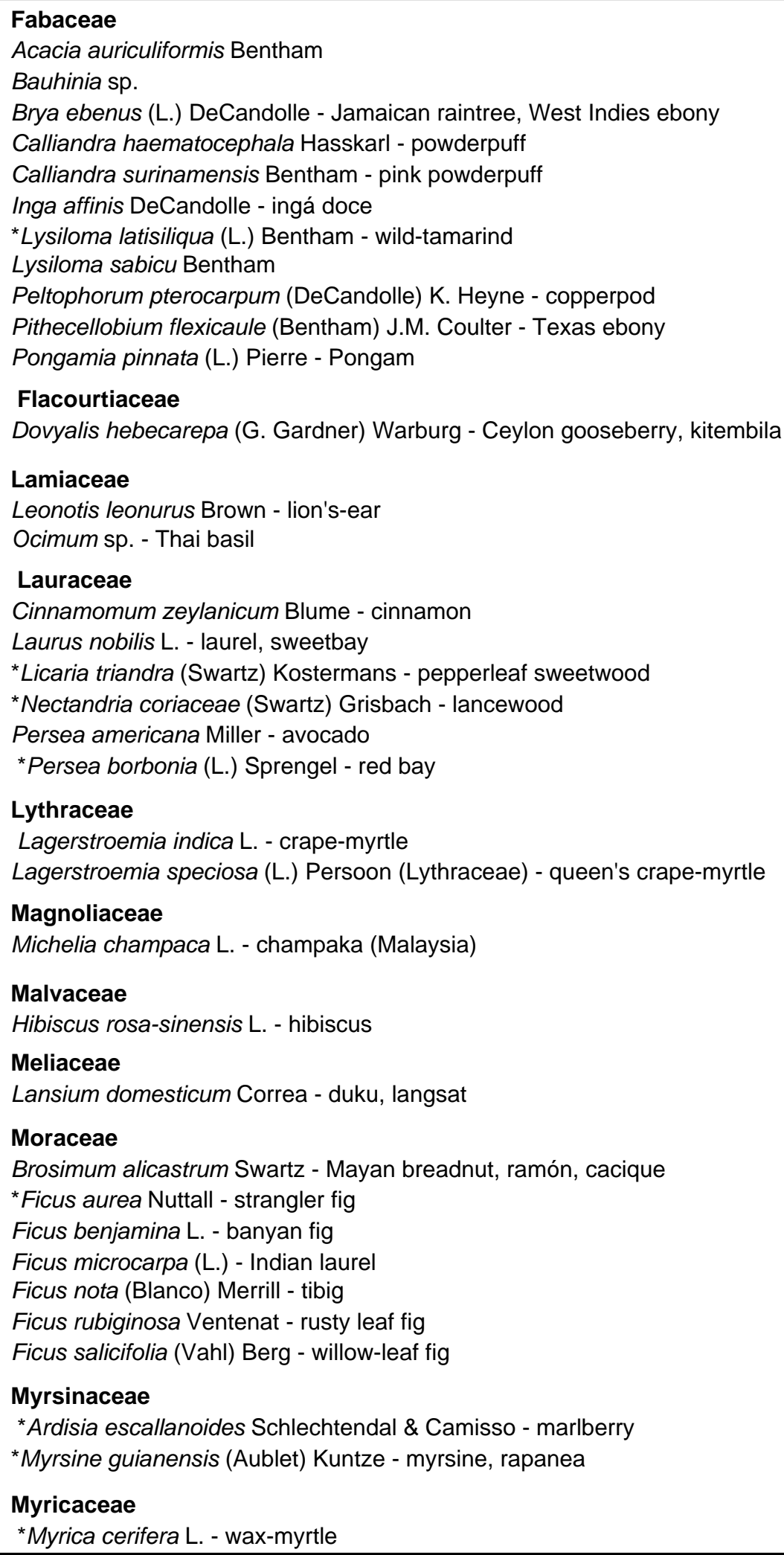

\section{Lythraceae}

Lagerstroemia indica L. - crape-myrtle 
Table 2. Lobate lac scale: Host list by family as of October, 2002.

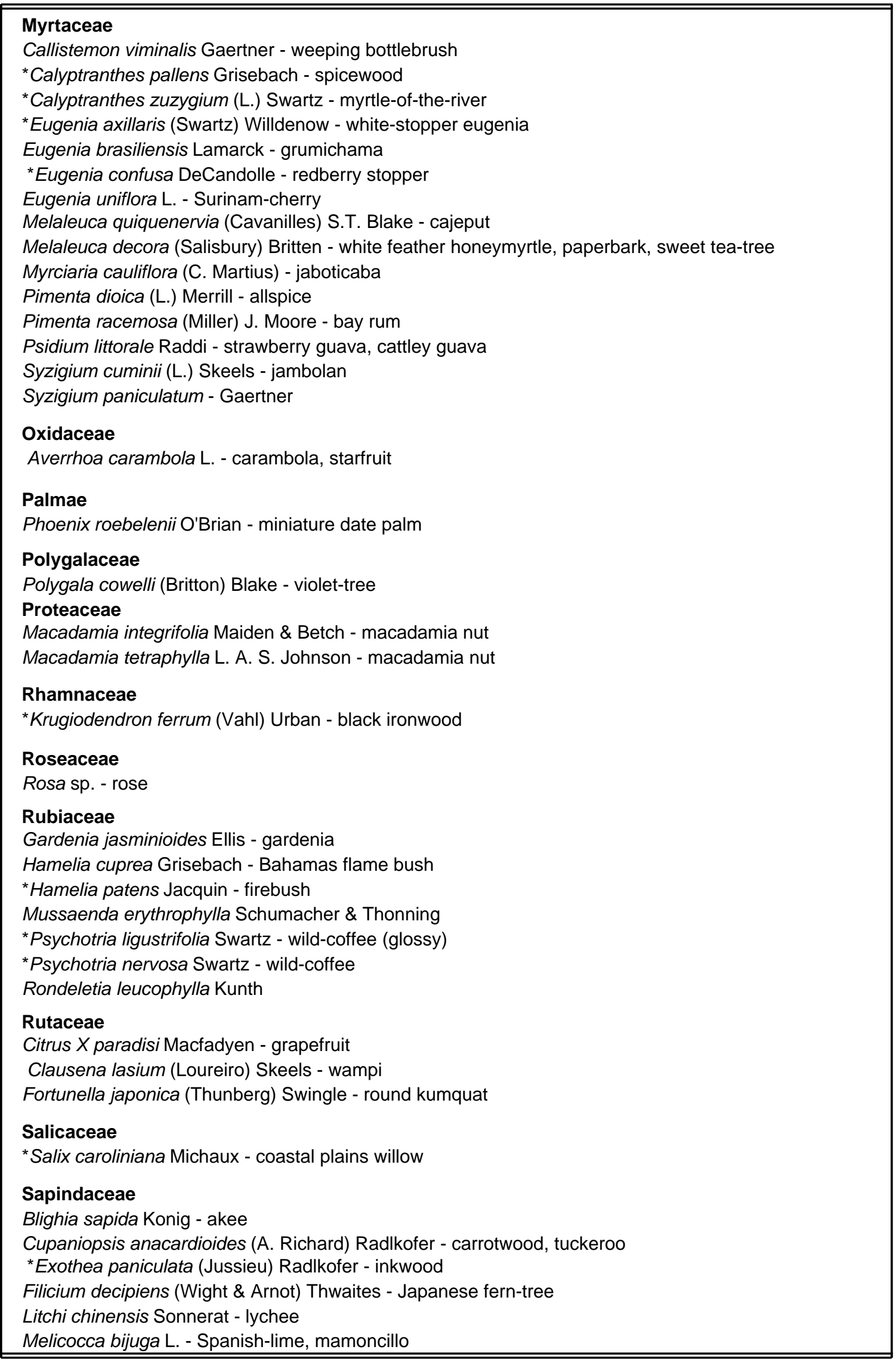


Table 2. Lobate lac scale: Host list by family as of October, 2002.

\begin{tabular}{l}
\hline \hline Sapotaceae \\
${ }^{*}$ Bumelia celastrina Humboldt, Bonpland \& Kunth - saffron-plum \\
Chrysophyllum cainito L. - star-apple \\
${ }^{*}$ Chrysophyllum oliviforme L. - satinleaf \\
${ }^{*}$ Dipholis salicifolia (L.) Alphonse De Candolle - willow bustic \\
${ }^{*}$ Manilkara jaimiqui (C. Wright) Dubard ssp. Emarginata (L.) Cronquist - wild-dilly \\
Manilkara (Achras) zapota (L.) Van Royen ) - sapodilla, nispero \\
${ }^{*}$ Mastichodendron foetidissimum (Jacquin) H. J. Lam - false-mastic \\
Mimusops elengi L. - Spanish-cherry \\
Synsepalum dulcificum Schumacher \& Thonning - miracle fruit \\
Solanaceae \\
Brunfelsia sp. \\
Brunfelsia nitida Bentham - lady-of-the-night \\
Cestrum nocturnum L. - night-blooming jessamine \\
Tiliaceae \\
Grewia occidentalis L. - starflower \\
Verbanaceae \\
Petrea volubilis Jaquin - queen's wreath \\
Vitaceae \\
${ }^{*}$ Parthenocissus quinqefolia (L.) Planchon - Virginia-creeper \\
\hline \hline
\end{tabular}

